\title{
Growth, Yield, Economics, Water Use Efficiency and Microbial Functions of Pigeon Pea Crop influenced by Drip Irrigation with Plastic Mulch
}

\author{
K.V. Ramana Rao, Pushplata Aherwar, Suchi Gangwar*, \\ Kumar Soni and Deepika Yadav
}

Irrigation and Drainage Engineering Department, ICAR-CIAE, Bhopal (M.P.)-462038, India

*Corresponding author:

\section{Keywords \\ Pigeon pea, Yield, Economics, WUE \\ (kg/ha mm), \\ Microbiological count etc.}

\section{Article Info}

Accepted:

17 November 2018 Available Online:

10 December 2018

\section{A B S T R A C T}

A field experiment was conducted during June-January seasons of 2016-17 and 2017- 18 at ICAR- Central Institute of Agricultural Engineering, Bhopal to study the growth, yield and economics of pigeon pea cultivation under drip irrigation in combination with plastic mulching. The study was laid out in randomized block design with four treatments viz., control, drip irrigation, drip with black mulch and drip with silver mulch and replicated five times. The yield attributes viz., plant height $(342 \mathrm{~cm})$, no of branches (17), pods per plant (1070), seeds per pod (3.78), yield (4330 kg/ha), hundred seed weight (13.89 g) and stalk yield $(9932 \mathrm{~kg} / \mathrm{ha})$ were found maximum under silver colour mulch treatment followed by black colour mulch. Water use efficiency (WUE) was found highest (7.6 $\mathrm{kg} / \mathrm{ha}-\mathrm{mm}$ ) for crop cultivated with drip irrigation under silver colour mulch as compared to other treatments. Cost of cultivation was higher under the mulching conditions (Rs 65936/ha) as compared to flood irrigation (Rs 20936/ha). However, the net returns were highest under silver mulch (Rs 128914 /ha) followed by black mulch (Rs 111724/ha) over flood irrigation (Rs 25864/ha). The B: C ratio was also higher under silver mulch (2.96) followed by black mulch (2.69) as compared to drip irrigation (2.08) and without mulch (1.91). The net seasonal return, benefit cost ratio and water use efficiency were found to be highest for pigeon pea under drip irrigation with silver mulch followed by black mulch.

\section{Introduction}

Pigeon pea (Cajanus cajana L. Millsp.) commonly known as red gram, tur or arhar is the fifth prominent legume crop in the world and important crop amongst pulses which ranks second after chickpea in India in terms of area and production. India has virtual monopoly in pigeon pea production accounting to $90 \%$ of world's total production.
In India alone, pigeon pea are grown in about 3.90 million hectares, with a production of 3.17 million ton, however the average productivity is only $0.81 \mathrm{t} / \mathrm{ha}$ (GOI, 2015).

More than $85 \%$ area of pigeon pea is under rain fed condition (Sanjay et al., 2017). However there is a wide scope for increase its production by sound soil and water management practices. 
The surface irrigation methods viz., furrow irrigation and controlled flooding i.e. ridges and furrow are the most common methods of irrigating pigeon pea. Loss of water during conveyance by evaporation and percolation leading to low application and distribution efficiency and generally observed with these irrigation systems.

The use of modern irrigation systems, like drip provides better crop growth and greater yields, due to efficient application of water and nutrients near the vicinity of plant root zone. In drip irrigation water is saved water due to reduction in conveyance, percolation, evaporation losses besides improving field application and distribution irrigation efficiencies and ultimately resulting in higher water use efficiency (Jadhav et al., 2018). However, under drip irrigation the weed infestation is expects though in lesser percentage as compared to flood irrigation.

Plastic mulching improve soil physical condition by enhancing aggregation and conserving soil moisture, preventive water logging conditions near root zone checking losses by evaporation and run off. It also favourably modifies the soil thermal regime, retards soil erosion and improves soil health. Apart from those the plastic mulching increases the soil temperature and moisture of upper layer of soil.

Plastic mulching techniques have been shown to be effective for increasing grain yield of crops. It induces the early crop emergences and also longer growth and maturity period. In India use of plastic film as mulch in field crops is of late gaining accessibility. Swathi reported (2018) that the congenial environmental conditions determine the growth and flowering behaviour of pigeon pea. Hence, the present work has been taken up to explores growth, yield, economics, water use efficiency and microbiological functions of pigeon pea through drip with plastic mulching by providing congenial soil and water conditions near the plant root zone.

\section{Materials and Methods}

\section{Description of study area}

The research work was carried out at ICARCentral Institute of Agricultural Engineering, Bhopal. Soils of the experimental site are classified as heavy clay soils with clay content varying between 49.7 to $53.7 \%$ and with the field capacity ranging from 28.5 to $31 \%$.The study area is located at North of Bhopal at $77^{\circ}$ $24^{\prime} 10^{\prime \prime} \mathrm{E}, 23^{\circ} 18^{\prime} 35^{\prime \prime} \mathrm{N}$ at an elevation of 495 $\mathrm{m}$ above mean sea level.

\section{Crop details}

Pigeon pea crop (JKM-189) was sown at a spacing of $1.2 \mathrm{~m} \mathrm{X} 1.2 \mathrm{~m}$. Plant protection measures were adopted to keep crop free from insect and diseases. Five randomly selected plants for each treatments after the germination were used to record average plant height, no of branches per plant, no of pods per plant, SPAD value, canopy temperatures $\left({ }^{0} \mathrm{C}\right)$, seed weight $(\mathrm{g})$, yield $(\mathrm{kg} / \mathrm{ha})$ and stalk yield ( $\mathrm{kg} / \mathrm{ha})$. Plant height was measured by the meter scale from the ground surface to the top of the. Chlorophyll content, an indication of the growth status of the plant was measured on 45 days after transplanting by SPAD meter. Canopy temperatures were measured by IRthermometer (Model IDR- 42512) at different treatments.

\section{Statistical analysis}

The collected data were analyzed by using fisher's analysis of variance technique and RBD test at 5\% to compare the difference among treatments means (Steel et al., 1997). Four treatments (T1-Flood irrigation, T2-drip irrigation, T3-mulching with black and T4- 
mulching with silver polythene films of 25 micron thickness) were tested with five replications.

\section{Water use efficiency (kg/ha-mm)}

Irrigation was applied with drip irrigation system alternate day and in line dripper spread at $1.5 \mathrm{~m}$ on every emitter flow rate of $2 \mathrm{l} / \mathrm{h}$ was used in the study. Water use efficiency (WUE) was also worked out by using following formula.

$$
\text { WUE }=\frac{\text { Seed yield }(\mathrm{kg} / \mathrm{ha})}{\text { Water applied through irrigation }(\mathrm{mm})}
$$

\section{Microbial analysis}

Soil samples were collected from all treatments of pigeon pea crop (variety JKM189). The samples were collected from three different points at different depths (0-15 and $15-30 \mathrm{~cm}$ ) from both the fields for analysis. The soil samples from each point were bulked and thoroughly mixed in a plastic bag, and composite samples was taken. The composite samples for each sub-areas and depth were air dried and sieved with $2 \mathrm{~mm}$ sieve by following standard procedures (Anonymous, 2011).

\section{Analysis}

Microbial properties of soil were assessed in terms of soil microbial biomass carbon (MBC) and total viable microbial count. Soil MBC was determined by the chloroform fumigation extraction method (Vance et al., 1987).

The number of living microorganisms was estimated by serial dilution planting technique. A series of 10 fold dilutions of the samples were prepared starting with $10 \mathrm{ml}$ of sterilized distilled water added to $1.0 \mathrm{~g}$ of soil sample. The flask was then closed and the contents were stirred for $30 \mathrm{~min}$, and $1.0 \mathrm{ml}$ suspension of sample was added to $9.0 \mathrm{ml}$ of sterilized distilled water. The dilutions were repeated to produce six continuous dilutions. Finally, 0.1 $\mathrm{ml}$ from each serial dilutions of the sample suspension was spread over an agar plate with beef extract peptone medium for bacteria in triplicates. The plates were incubated at $28^{\circ} \mathrm{C}$ until colonies appeared and colony forming units (CFU) were counted which varied from 30 to 300 colonies.

\section{Field layout and experiment details}

The experimental field of pigeon pea is square in shape with $20 \mathrm{~m}$ long and $20 \mathrm{~m}$ wide and plant to plant distance is $1.2 \mathrm{~m}$ and row to row distance is $1 \mathrm{~m}$. A $12 \mathrm{~mm}$ diameter laterals using online drippers having discharge of $4 \mathrm{lps}$ were installed for irrigating the crop.

The distribution of water in different laterals was controlled by lateral control valve provided at the entry end of each lateral. The operating pressure of about $1 \mathrm{~kg} / \mathrm{cm}^{2}$ was maintained to obtain designed dripper discharge. The layout of the field and the division of plots along with the lateral fitted with drippers is shown in figure 1 .

Different irrigation systems such as flood irrigation, drip irrigation alone and drip irrigation with black plastic and silver mulch were considered as treatments of experiment.

\section{Results and Discussion}

\section{Plant growth parameters}

Influence of drip irrigation systems with plastic mulch in pigeon pea was evaluated continuously for two years. The average values of the crop growth parameters collected for the crop in each treatment for the two years were pooled and the values are presented in Table 1. 
Table.1 Growth yield of pigeon pea influence by drip irrigation with plastic mulch (Two years pooled data)

\begin{tabular}{|c|c|c|c|c|c|c|c|c|c|}
\hline Treatments & $\begin{array}{l}\text { Plant height } \\
\text { (cm) }\end{array}$ & $\begin{array}{l}\text { No of } \\
\text { branches }\end{array}$ & $\begin{array}{l}\text { SPAD } \\
\text { value }\end{array}$ & $\begin{array}{c}\text { Canopy } \\
\text { temp } \\
\left({ }^{\circ} \mathrm{C}\right)\end{array}$ & $\begin{array}{c}\text { No of pods per } \\
\text { plant }\end{array}$ & $\begin{array}{c}\text { No of seed } \\
\text { per pod }\end{array}$ & $\begin{array}{c}100 \text { seed } \\
\text { weight }(g)\end{array}$ & $\begin{array}{l}\text { Yield } \\
\text { (kg/ha) }\end{array}$ & $\begin{array}{c}\text { Stalk } \\
\text { yield } \\
(\mathrm{Kg} / \mathrm{ha})\end{array}$ \\
\hline Flood irrigation & 120 & 06 & 45.03 & 31.45 & 170 & 2.20 & 12.74 & 889 & 3652 \\
\hline Drip irrigation & 280 & 10 & 45.46 & 32.05 & 650 & 2.47 & 13.10 & 2356 & 5217 \\
\hline Black mulch & 324 & 14 & 46.89 & 32.48 & 930 & 3.56 & 13.60 & 3948 & 9874 \\
\hline Silver mulch & 342 & 17 & 46.22 & 32.14 & 1070 & 3.78 & 13.89 & 4330 & 9932 \\
\hline SEM \pm & 6.45 & 1.16 & 1.89 & 3.26 & - & 0.07 & 0.56 & - & - \\
\hline $\mathrm{CD}(0.05 \%)$ & 19.03 & 3.48 & NS & NS & - & 0.20 & NS & - & - \\
\hline
\end{tabular}

Table.2 Microbial Count of mulched and open field soil at different depths (Two years pooled data)

\begin{tabular}{|c|c|c|c|}
\hline S.N & Soil Sample & Depth & CFU/g \\
\hline 1. & Flood irrigation & $0-15 \mathrm{~cm}$ & $11.3 \times 10^{3}$ \\
& & $15-30 \mathrm{~cm}$ & $1.5 \times 10^{3}$ \\
\hline 2. & Drip irrigation & $0-15 \mathrm{~cm}$ & $17.5 \times 10^{3}$ \\
& & $15-30 \mathrm{~cm}$ & $2.6 \times 10^{3}$ \\
\hline 3. & Black mulch & $0-15 \mathrm{~cm}$ & $10 \times 10^{6}$ \\
& & $15-30 \mathrm{~cm}$ & $4.1 \times 10^{6}$ \\
\hline 4. & Silver mulch & $0-15 \mathrm{~cm}$ & $10 \times 10^{6}$ \\
& & $15-30 \mathrm{~cm}$ & $4.4 \times 10^{6}$ \\
\hline
\end{tabular}

Table.3 Economics of pigeon pea (Two years pooled data)

\begin{tabular}{|c|c|c|c|c|}
\hline Treatments & $\begin{array}{c}\text { Total cost of } \\
\text { cultivation (Rs/ha) }\end{array}$ & $\begin{array}{c}\text { Gross Monetary } \\
\text { Return (Rs/ha) }\end{array}$ & $\begin{array}{c}\text { Net Monetary } \\
\text { Return (Rs/ha) }\end{array}$ & \begin{tabular}{c} 
B:C \\
\hline Flood irrigation
\end{tabular} \\
\hline Drip irrigation & 19936 & 40005 & 20069 & 2.00 \\
\hline Black mulch & 50936 & 106020 & 55084 & 2.08 \\
\hline Silver mulch & 65936 & 177660 & 111724 & 2.69 \\
\hline
\end{tabular}


Fig.1 Layout of experimental field

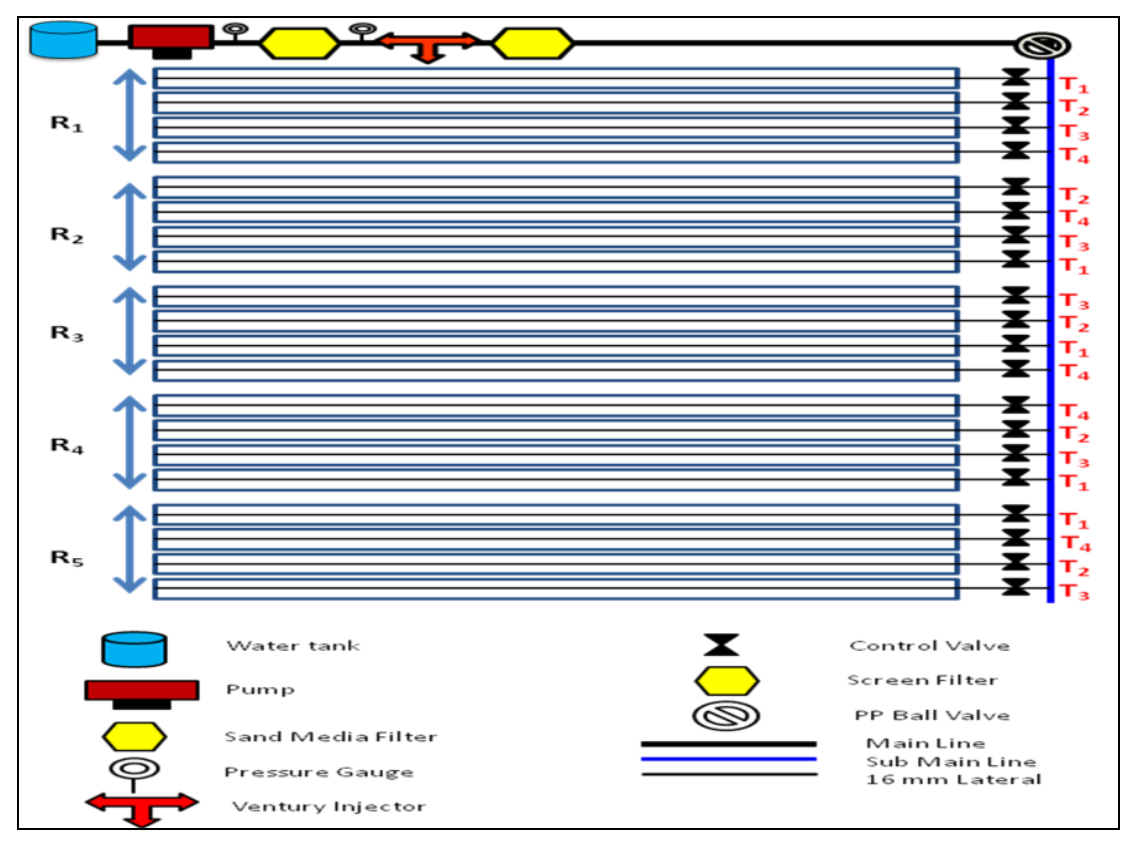

Fig.2 WUE (kg/ha-mm) of Pigeon pea under different treatments

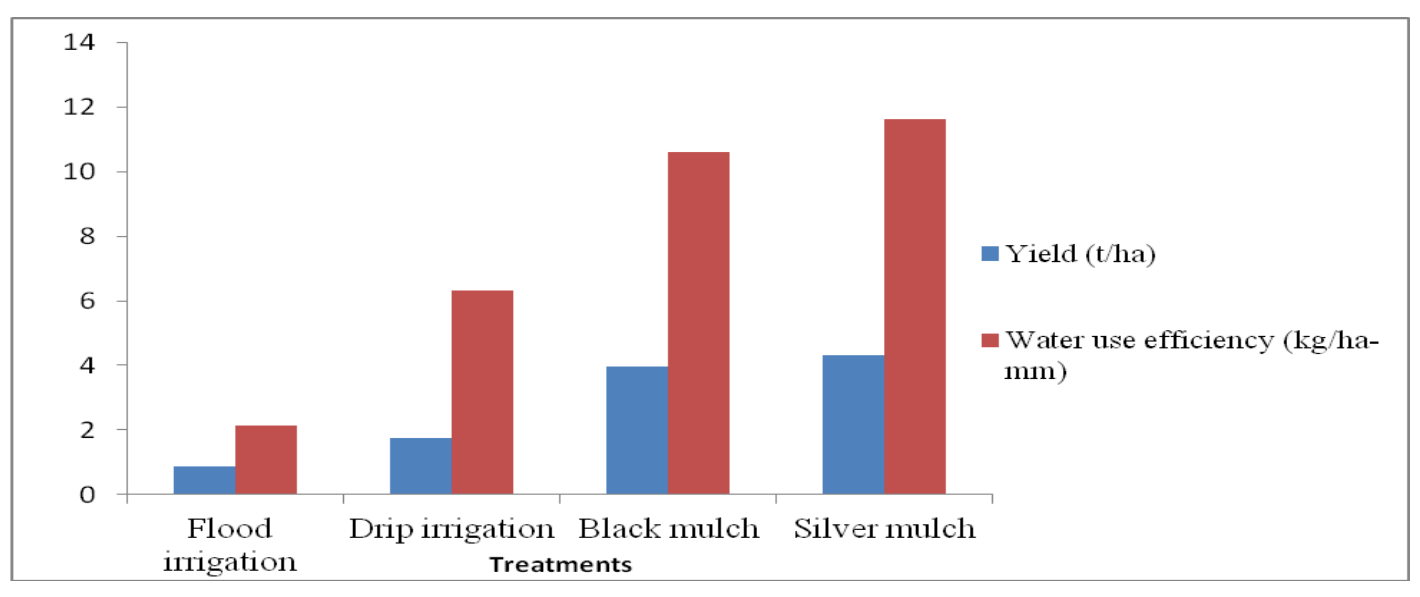


The plant growth parameters such as average plant height were highest under silver plastic mulch $(342 \mathrm{~cm})$ as compared to black plastic mulch $(324 \mathrm{~cm})$, drip irrigation $(280 \mathrm{~cm})$ and flood irrigation $(120 \mathrm{~cm})$. Average number of branches per plant, SPAD value and canopy temperature $\left({ }^{\circ} \mathrm{C}\right)$ were also higher in silver mulch followed by black mulch, drip irrigation and lowest in flood irrigated pigeon pea crop. Increase in spacing and use of plastic mulch enhanced the individual plant performance. Further, it might have improved the rate of photosynthesis, dry matter accumulation and its translocation to pods as reflected in terms of higher values of growth and yield components.

\section{Yield parameters}

The results are in agreement with the findings of Meena et al., (2015) and Waghmare et al., (2016). Highest seed yield (4330 kg/ha) were recorded in silver plastic mulch as compared to black plastic mulch $(3948 \mathrm{~kg} / \mathrm{ha})$, drip irrigation $(2356 \mathrm{~kg} / \mathrm{ha})$ and flood irrigation $(889 \mathrm{~kg} / \mathrm{ha})$. The better availability of growth resources like water, nutrients, air, mulching, better cultural practices and effective weed control in mulch helped the plants to exhibit their full potential and produced higher yield than open field condition. The results are in agreement with the findings of Meena et al., (2015), Waghmare et al., (2016) and Gajera et al., (2002). Higher stalk yield were recorded in silver plastic mulch (9932 kg/ha) as compared to black plastic mulch $(9874 \mathrm{~kg} / \mathrm{ha})$ and drip irrigation (5217 $\mathrm{kg} / \mathrm{ha}$ ) and lowest stalk yield recorded in flood irrigation condition $(3652 \mathrm{~kg} / \mathrm{ha})$. The treatments under plastic mulch film has more amount of soil moisture higher nutrients levels, was due to increased dry matter production per plant and resulting in good response of pigeon pea for irrigation at all the stage of crop growth under mulching conditions (Fig. 2).

\section{Economics}

The highest net return (128914 Rs/ha) were recorded in silver colour plastic mulch as compared to black colour plastic mulch (111724
Rs/ha), drip irrigation (55084 kg/ha) and flood irrigation $(20069 \mathrm{~kg} / \mathrm{ha})$. The highest BCR were recorded in silver plastic mulch (2.96) followed by black plastic mulch (2.69) then drip irrigation (2.08) and flood irrigation (2.00).

\section{Water use efficiency (kg/ha mm)}

At silver colour mulch recorded highest WUE $(7.2 \mathrm{~kg} / \mathrm{ha} \mathrm{mm})$ followed by black mulch $(6.68$ $\mathrm{kg} / \mathrm{ha} \mathrm{mm})$ over no mulch condition $(5.6 \mathrm{~kg} / \mathrm{ha}$ $\mathrm{mm})$. This is in agreement with the results of (Kar and Kumar, 2007) who reported significantly higher WUE in the mulched plots compared to no mulched plots in case of potato crop.

\section{Microbiological properties of soil}

The mulching has shown a positive impact on microbial content of soil by lessening physiological stress especially due to moisture availability which helps microbial flora to flourish and decompose organic matter efficiently.

A close perusal of table 2 reveals that the soil microbial biomass carbon has decreased with depth. This might be due to decrease of soil organic carbon content with soil depth. Mulching has influenced the microbial population positively showing higher microbial count in plastic mulched field. This may be due to proper maintenance of abiotic factors like soil moisture, temperature, soil structure and nutrients. The interaction between biotic and abiotic factors leads to better crop growth and yield. A significantly higher population of microbes was reported in the upper soil horizon $(0-15 \mathrm{~cm})$ as governed by the fact that number of microorganisms decreases with depth.

\section{Acknowledgements}

Authors would like to extend their gratitude to the Director, CIAE, and the Head, Irrigation and Drainage Engineering Division, CIAE, Bhopal for permitting them to do this research work. Authors are also grateful to funding agency 
NCPAAH (National Committee on Plasticulture Application in Horticulture) which give fund for research work.

\section{References}

Anonymous. 2011. Methods Manual Soil Testing in India, Dept of Agriculture \& Cooperation, Ministry of Agriculture, Govt of India 217p.

Gajera M.S and Ahlawat R.P.S. (2002). Effect of different depth of ploughing and mulches on moisture extraction and yield of rabi pigeonpea (Cajanus cajan (L.) Millsp.).Legume Research. 25(3): 165169.

GoI. 2015. Agricultural Statistics at a Glance 2015. Directorate of Economics and Statistics, Department of Agriculture, Cooperation and Farmers Welfare, Ministry of Agriculture and Farmers Welfare, Krishi Bhawan, New Delhi.

K.T. Jadhav, A.S. Chavan, S.K. Raskar and R.U. Lahase (2018). Influence of Spacing and Drip Irrigation on Yield Attributes, Productivity and Economics of Pigeonpea (Cajanus cajan L.) International Journal of Current Microbiology and Applied Sciences 7(2): 3498-3506

Kar G and Kumar A (2007) Effect of irrigation and straw mulch on water use and tuber yield of potato in eastern India. Agril Water Management 94(1-3): 109-116.

Meena B.K, Hulihalli U.K and Sumeriya H.K. (2015). Growth, yield attributed and yield of medium duration pigeonpea hybrid ICPH2671 as influenced by fertility levels and planting geometry. Legume Research 38(6): 816-820.

Reddy Y.A, Sagar RVKR, Reddy G.P and Pushpavathi Y. (2016). Response of pigeon pea [Cajanus cajan (L.) Millsp.] varieties to varying plant population during rabi in southern agro-climatic zone of Andhra Pradesh. International Journal of Agricultural Science and Research 6 (6): $73-76$.

Sanjay U. Kakade, Lomesh A. Mohurle, J.P. Deshmukh and Anita B. Chorey (2017). Effect of drip fertigation on growth, yield and economics of pigeonpea. Int. J. Pure App. Biosci 5 (5): 1092-1098

Steel RGD, Torrie J.H and Dicky D.A. (1997). Principles and procedures of Statistics, A Biometrical Approach $3^{\text {rd }}$ Ed. McGraw Hill Book Co. Inc., New York, USA.

Vance E.D., Brookes, P.C. and Jenkinson, D.S. 1987. An extraction method for measuring soil microbial biomass C. Soil Biol. Biochem 19:703-707.

Waghmare Y.M, Gokhale D.N and Chavan A.S. (2016). Production potential of pigeonpea [Cajanus cajan (L.) Millsp] as influenced by plant geometry and irrigation schedules. International Journal of Agricultural Sciences 8(16): 1287-1289.

Y.M. Swathi, M. Srinivasa Reddy, G. Prabhakara Reddy and P. Kavitha (2018). Efficacy of Polyethylene Mulch Technology in Improving Growth, Flowering Behavior and Yield of Irrigated Pigeonpea in Andhra Pradesh. Int.J.Curr.Microbiol.App.Sci Special Issue-6: 1769-1773.

\section{How to cite this article:}

Ramana Rao, K.V., Pushplata Aherwar, Suchi Gangwar, Kumar Soni and Deepika Yadav. 2018. Growth, Yield, Economics, Water Use Efficiency and Microbial Functions of Pigeon Pea Crop influenced by Drip Irrigation with Plastic Mulch. Int.J.Curr.Microbiol.App.Sci. 7(12): 2284-2290. doi: https://doi.org/10.20546/ijcmas.2018.712.259 